\title{
The Nutritional Content of Common Bean (Phaseolus vulgaris L.) Landraces in Comparison to Modern Varieties
}

\author{
Tugce Celmeli, Hatice Sari ${ }^{(D)}$, Huseyin Canci, Duygu Sari, Alper Adak ${ }^{(D)}$, Tuba Eker \\ and Cengiz Toker * (D) \\ Department of Field Crops, Akdeniz University, Faculty of Agriculture, Antalya TR 07070, Turkey; \\ tucee_celmeli@hotmail.com (T.C.); haticesari@akdeniz.edu.tr (H.S.); huseyincanci@akdeniz.edu.tr (H.C.); \\ duygusari@akdeniz.edu.tr (D.S.); alperadak@akdeniz.edu.tr (A.A.); ekertuba07@gmail.com (T.E.) \\ * Correspondence: toker@akdeniz.edu.tr; Tel.: +90-242-3102421
}

Received: 9 July 2018; Accepted: 22 August 2018; Published: 27 August 2018

\begin{abstract}
In terms of safe food and a healthy food supply, beans (Phaseolus spp.) are a significant source of protein, carbohydrates, vitamins and minerals especially for poor populations throughout the world. They are also rich in unsaturated fatty acids, such as linoleic and oleic acids. From the past to the present, a large number of breeding studies to increase bean yield, especially the common bean (P. vulgaris L.), have resulted in the registration of many modern varieties, although quality and flavor traits in the modern varieties have been mostly ignored. The aim of the present study, therefore, was to compare protein, fat, fatty acid, and some mineral content such as selenium (Se), zinc $(\mathrm{Zn})$ and iron $(\mathrm{Fe})$ of landraces to modern varieties. The landrace LR05 had higher mineral contents, particularly Se and Zn, and protein than the modern varieties. The landrace LR11 had the highest linoleic acid. The landraces are grown by farmers in small holdings for dual uses, such as both dry seed and snap bean production, and are commercialized with a higher cash price. The landraces of the common bean are, not only treasures that need to be guarded for the future, but also important genetic resources that can be used in bean breeding programs. The results of this study suggest that landraces are essential sources of important nutritional components for food security and a healthy food supply.
\end{abstract}

Keywords: common bean; Phaseolus vulgaris; protein; fat; fatty acids; iron; zinc; selenium

\section{Introduction}

The genus Phaseolus L. consists of 76 species from the New World [1], and five species, tepary bean (P. acutifolius A. Gary), runner bean (P. coccineous L.), lima bean (P. lunatus L.), year-bean (P. polyanthus Greenman) and common bean (P. vulgaris L.), are under cultivation in the world [2,3]. Among the cultivated species, the common bean is dominant with a growing area ratio of $90 \%$ [4]. It is not only used as a dry grain and snap bean as vegetables but is also in the market as a canned product like industrial crops. Global production as a dry grain is 26.8 million tons, while production as a vegetable or snap bean is 23.5 million tons according to the database of the Food and Agriculture Organization (FAO) in 2016. The yields as dry grain and snap bean are $913 \mathrm{~kg}$ per ha and $1515 \mathrm{~kg}$ per ha, respectively [5]. The common bean can also fix more than $160 \mathrm{~kg}$ of atmospheric nitrogen per ha into soil via interactions with Rhizobium bacteria [6]. Because of their high protein, mineral and fiber content, beans are consumed instead of meat in underdeveloped and developing countries [7]. However, especially in the last decade, the benefits of beans have been better understood in terms of high protein, important minerals, dietary fiber and some vitamins, so consumption has also increased in developed countries [8]. 
Some water-soluble vitamins such as thiamin, riboflavin, niacin, vitamin $\mathrm{B}_{6}$ and folic acid and minerals including potassium $(\mathrm{K})$, calcium $(\mathrm{Ca})$, magnesium $(\mathrm{Mg})$, zinc $(\mathrm{Zn})$, copper $(\mathrm{Cu})$ and iron $(\mathrm{Fe})$ were identified in the common bean [9]. Sangronis and Machado [10] identified phytic acid, tannins, ascorbic acids, thiamin, protein digestibility and $\mathrm{Ca}, \mathrm{Mg}, \mathrm{Zn}, \mathrm{Fe}$ and $\mathrm{Cu}$ in the common bean [10]. In four genotypes of bean, Barampama and Simard [11] studied protein, ash, fat, some minerals ( $\mathrm{K}, \mathrm{Ca}$, $\mathrm{Mg}, \mathrm{Fe}, \mathrm{Cu}, \mathrm{Zn}$ and $\mathrm{P}$ ), the essential amino acids (isoleucine, leucine, lysine, methionine, phenylalanine, threonine and valine) and some antinutritional factors (raffinose oligosaccharide, trypsin inhibitor, hemagglutinin, tannin and phytic acid) were determined. Correlations among mineral contents (Mn, $\mathrm{Zn}, \mathrm{Ca}, \mathrm{Mg}, \mathrm{K}$ and $\mathrm{P}$ ) in an intraspecific cross of two accessions of common beans were reported by Beebe et al. [12]. Protein and mineral contents consisting of $\mathrm{Ca}, \mathrm{Fe}$ and $\mathrm{Zn}$ were found in both common and wild beans [13]. Protein lipids, fiber and minerals such as $\mathrm{Ca}, \mathrm{Fe}, \mathrm{Mg}$ and $\mathrm{Zn}$ have also been examined in the common bean [14]. The mineral composition (Sodium, $\mathrm{K}, \mathrm{Ca}, \mathrm{Mg}$, $\mathrm{Zn}, \mathrm{Cu}, \mathrm{Fe}$ and $\mathrm{Mn}$ ) and fatty acid profile (C14, C16, C18, C20, C24, C16:1, C18:1 and C22:1) were studied in the seeds of selected Fabaceae species including the common bean [15]. Zn contents were determined in common beans by Koehler et al. [16]. Some minerals including $\mathrm{Zn}$ and Fe were found in recombinant inbred lines (RILs) of the bean [17]. Common bean genotypes that were collected from various regions of India were evaluated for $\mathrm{Fe}, \mathrm{Zn}$ and protein contents [18]. Furthermore, $\mathrm{Mg}, \mathrm{K}, \mathrm{Fe}, \mathrm{Zn}, \mathrm{Mn}, \mathrm{Cu}$ and $\mathrm{Se}$ of some pulses including the common bean were determined [19].

One of the most important purposes of bean-related breeding studies is to increase the yield obtained from the unit area [4]. Many studies have reported that modern cultivars had lower levels of key micronutrients and vitamins due to focusing on high yield during domestication and post-domestication [20]. From 1961 to 2016, the mean seed yield of beans considerably increased by an average of $420 \mathrm{~kg}$ per ha because of new cultivars and technological applications in commercial production [5]. According to the available literature, there have been many studies to increase yield in the common bean [4] but breeding for protein, minerals, fat and fatty acids has been ignored. In addition to the increased yield of modern varieties, there is also the disadvantage of giving up the use of landraces and thereby causing them to suffer from genetic erosion [21]. Diversity was reduced by the process of domestication based on selection and environments [20]. As landraces are unique genetic resources, the potential of which has not yet been elucidated, there are some issues to be addressed in current and future breeding research. Landraces with their own flavor are produced and consumed by local producers in only a few parts of the world. In terms of food security and a healthy food supply, landraces are significant sources of protein, carbohydrates, vitamins and minerals throughout the world. Therefore, the aim of this study was to examine the protein, fat, fatty acids, Se, Fe and Zn content required for healthy and balanced nutrition, of landraces collected from the highlands of the Western Taurus Mountains, and to compare these values with modern varieties.

\section{Results}

\subsection{Protein Content}

Statistically significant differences were detected among accessions for protein content $(P<0.05)$. The protein contents of the landraces (LR) ranged from $16.54 \%$ to $25.23 \%$, while the protein contents of the modern varieties (MV) ranged from $19.70 \%$ to $24.30 \%$. The highest protein content was in LR05 $(25.23 \%)$, while the lowest protein content was in LR10 (16.54\%). The protein content of some landraces (LR07, LR10 and LR11) was lower than that of the modern varieties (Figure 1). 
$\square$ Protein

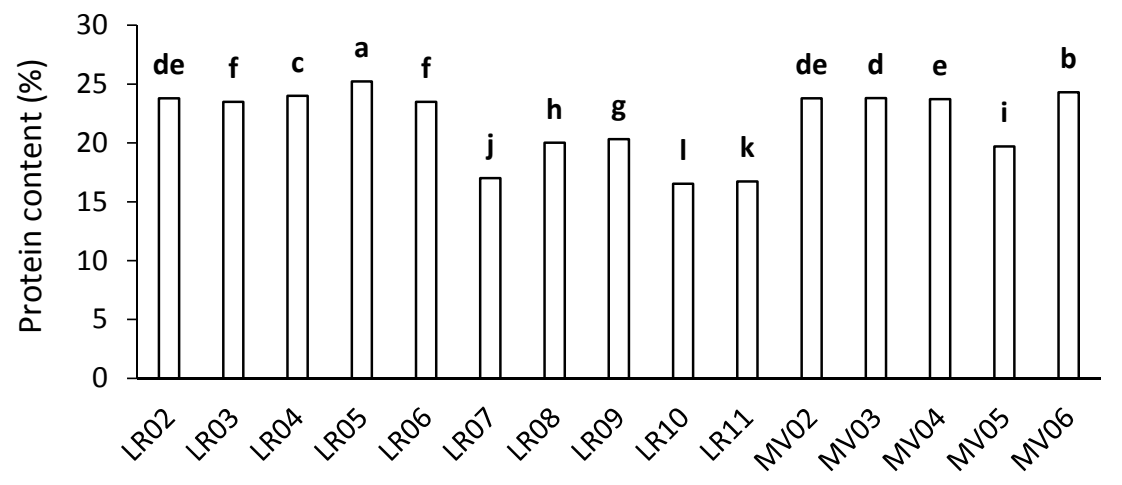

Figure 1. Crude protein of landraces (LR) and modern varieties (MV). Means followed by the same lower-case letters are not significantly different (Duncan's multiple range test (DMRT); $P<0.05$ ).

\subsection{Fat and Fatty Acids Composition}

There were no statistically significant differences among the accessions in respect of fat content, while there were statistically significant differences among the accessions for oleic and linoleic acids $(P<0.05)$. The fat content of the accessions ranged from $0.33 \%$ to $1.33 \%$. MV06 had the highest fat content (Figure 2). LR11 (18.60\%) had the highest content of linoleic acid, one of the important fatty acids, while MV06 (7.56\%) had the lowest linoleic acid content. The landraces (LR11, LR08 and LR06) had higher linoleic acid content than the modern varieties (Figure 2). MV06 (24.30\%) had the highest oleic acid content, followed by MV05 (22.41\%) and LR02 (22.07\%) (Figure 2).

$\square$ Fat (\%) $\quad$ Oleic acid (\%) $\quad$ Linoleic acid (\%)

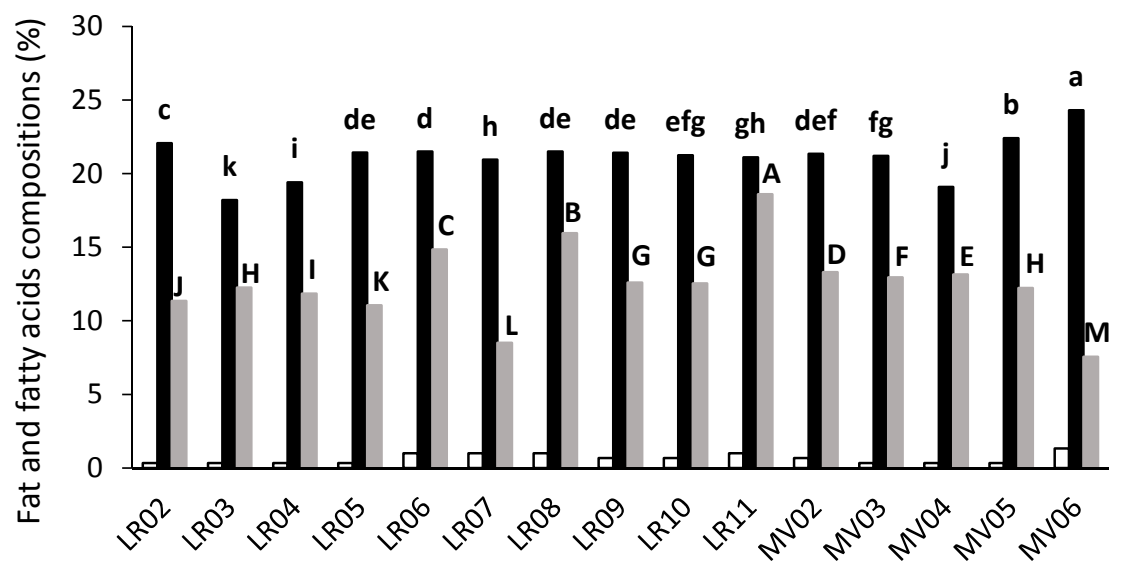

Figure 2. Fat and fatty acids compositions of landraces and modern varieties. Upper-case letters compare the beans for linoleic acid (gray bars), whereas lower-case letters for oleic acid (black bars). Means followed by the same upper- or lower-case letters are not significantly different (DMRT; $P<0.05$ ).

Mono-unsaturated fatty acids (MUFA) content ranged from $19.42 \%$ to $24.26 \%$ in landraces and from $21.90 \%$ to $25.86 \%$ in modern varieties (Figure 3). The three accessions with the highest MUFA content were MV06 (25.86\%), MV05 (24.78\%) and LR02 (24.26\%), respectively (Figure 3). The polyunsaturated fatty acid (PUFA) content of modern varieties ranged from $49.23 \%$ to $55.32 \%$, while landraces ranged from $40.33 \%$ to $53.16 \%$ (Figure 3). In terms of MUFA and PUFA content, there was no statistically significant difference among the accessions. The majority of landraces and modern varieties had over 50\% PUFA content and over 20\% MUFA content (Figure 3). 


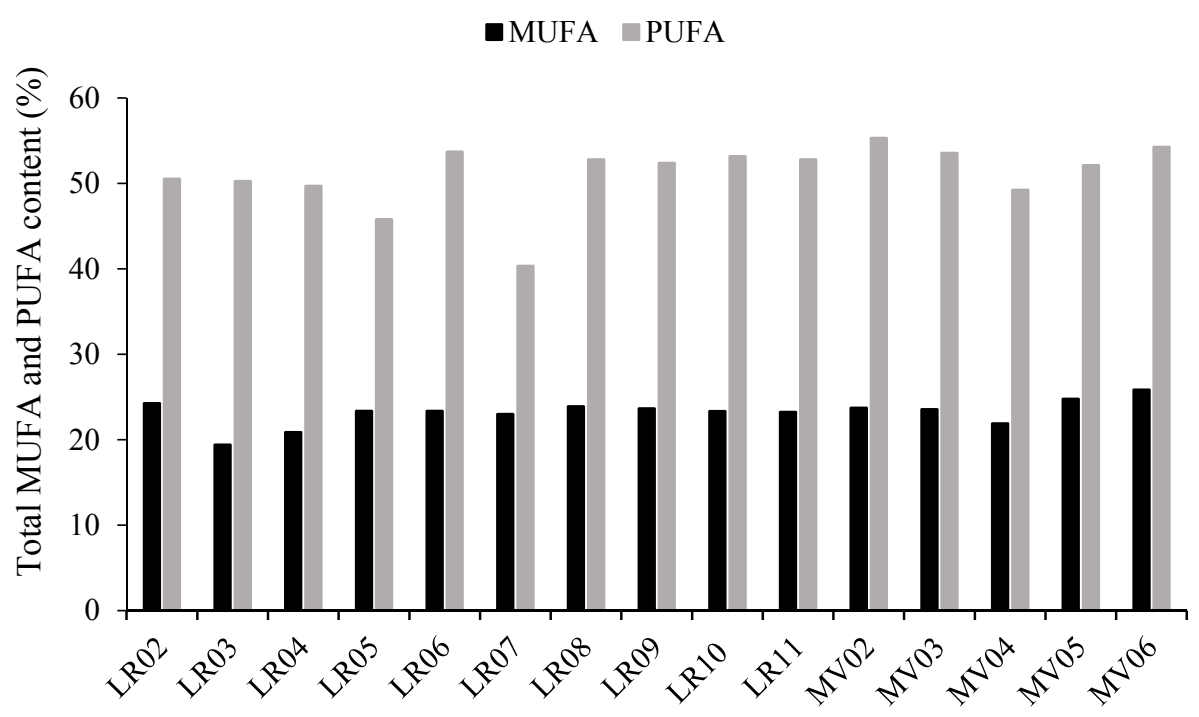

Figure 3. Total mono-unsaturated fatty acids (MUFA) and polyunsaturated fatty acid (PUFA) content of landraces and modern varieties.

\subsection{Mineral Contents}

$\mathrm{Se}, \mathrm{Zn}$ and $\mathrm{Fe}$ as mineral contents of the seeds of the accessions were determined in landraces and modern varieties. There was a statistically significant difference in Se content between landraces and modern varieties. The landrace LR05 had the highest Se content of $0.48 \mathrm{mg} / \mathrm{kg}$, followed by landrace LR11 at $0.15 \mathrm{mg} / \mathrm{kg}$ Se content landrace LR05 was found to be an approximately 2-3-fold higher level than that of the other accessions (Figure 4).

口Selenium $(\mathrm{mg} / \mathrm{kg})$

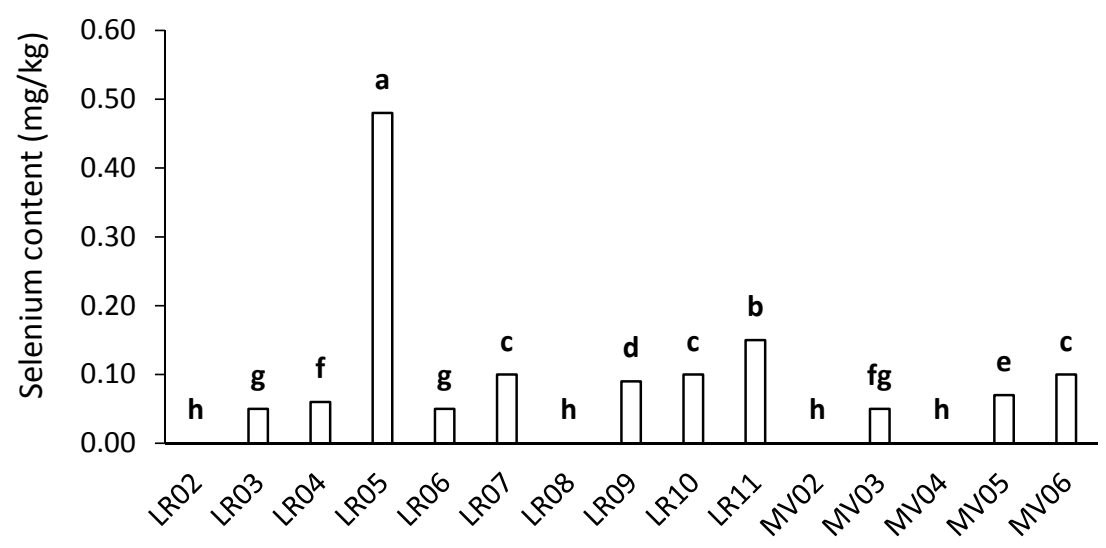

Figure 4. Se contents of landraces and modern varieties. Means followed by the same lower-case letters are not significantly different (DMRT; $P<0.05)$.

The highest Fe content was observed in MV03 (133.64 mg/kg), followed by MV04 (116.31 mg/kg) and LR10 (115.05 mg/kg) (Figure 5).

The $\mathrm{Zn}$ content of landraces ranged from 17.81 to $37.90 \mathrm{mg} / \mathrm{kg}$, while it ranged from 25.03 to $35.1 \mathrm{mg} / \mathrm{kg}$ in modern varieties. LR05 had the highest Zn content at $37.88 \mathrm{mg} / \mathrm{kg}$ (Figure 5). 


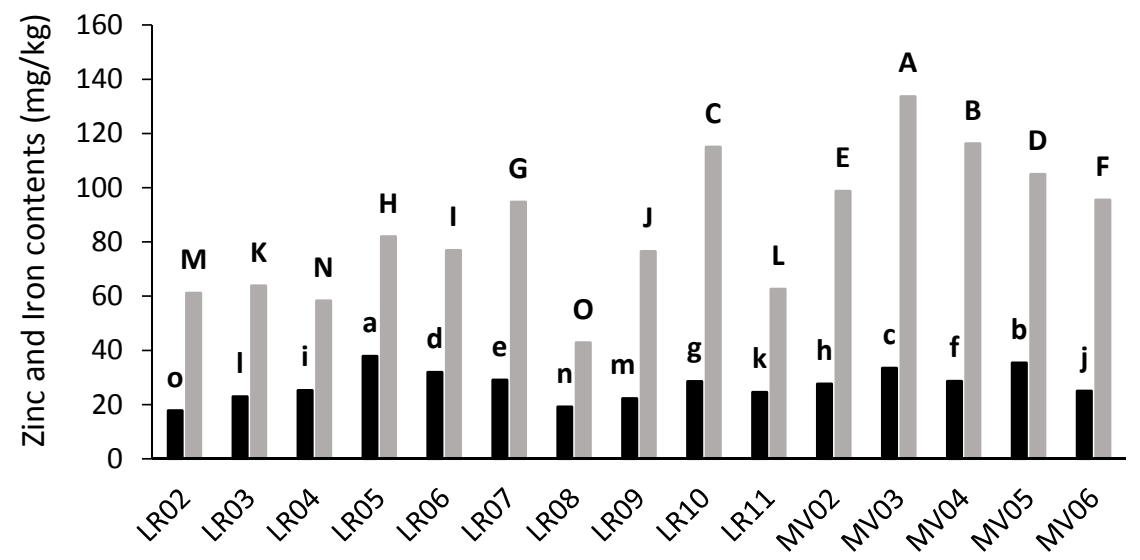

Figure 5. Zn and Fe contents of landraces and modern varieties. Upper-case letters compare the beans for Fe content (gray bars), and lower-case letters for Zn content (black bars). Means followed by the same upper- or lower-case letters are not significantly different (DMRT; $P<0.05$ ).

\subsection{Correlations}

The fat content in the seeds of accessions was positively correlated $(P<0.01)$ with oleic acid $(\mathrm{r}=0.531 * *)$, and negatively correlated with protein content $(\mathrm{r}=-0.368 *)$. A negative correlation was found between oleic acid and linoleic acid $(r=-0.304 *)$. Se was positively correlated $(P<0.01)$ with $\mathrm{Zn}\left(\mathrm{r}=0.541^{* *}\right)$, and the highest correlation $\left(\mathrm{r}=0.628^{* *}\right)$ was found between $\mathrm{Fe}$ and $\mathrm{Zn}(P<0.01)$. There was no significant correlation between the 100-seed weight and other traits (Table 1).

Table 1. Correlations among nutritional contents of landraces and modern varieties.

\begin{tabular}{cccccccc}
\hline Nutritional Contents & Protein & Fat & Oleic Acid & Linoleic Acid & Selenium & Zinc & Iron \\
\hline Fat & $-0.368^{*}$ & & & & & & \\
Oleic acid & -0.064 & $0.531^{* *}$ & & & & & \\
Linoleic acid & -0.233 & -0.091 & $-0.304^{*}$ & & & & \\
Selenium & 0.063 & -0.067 & 0.157 & -0.076 & & \\
Zinc & 0.112 & -0.231 & 0.070 & 0.015 & $0.541^{* *}$ & \\
Iron & 0.009 & -0.179 & 0.120 & -0.133 & -0.006 & $0.628^{* *}$ & \\
100-seed weight & -0.268 & 0.189 & 0.449 & -0.338 & 0.201 & 0.204 & 0.303 \\
\hline
\end{tabular}

${ }^{*}$ and ${ }^{* *}$ indicate that correlation is significant at the $0.05,0.01$ level, respectively.

\section{Discussion}

Some landraces were determined to have more protein content in their seeds than the modern varieties. The protein content of landraces was determined as $16.54 \%-25.23 \%$, while the protein content of modern varieties ranged from $19.70 \%-24.3 \%$ Landrace LR05 had the highest protein content at $25.23 \%$ (Figure 1). Guzman-Maldonado et al. [13] emphasized that the protein content of the cultivated bean $(16.6-24.6 \mathrm{~g} / \mathrm{kg})$ was less than that of wild beans $(18.8-33.3 \mathrm{~g} / \mathrm{kg})$. The protein content of P. vulgaris genotypes was reported as between $17.08 \%$ and $25.46 \%$ [22]. In the present study, the variation of protein content was considerably wider in landraces $(16.6 \%-26.2 \%)$ compared to the previously mentioned reports $[11,13,22]$. Bean protein in the dry seeds of the common bean has been seen to vary from $17 \%$ to $35 \%$ and consist of five fractions, comprising of globulin-1 (phaseolin), globulin-2, albumin, prolamine and alkali-soluble [23]. These fractions were not examined in the present study but landraces were considered to possess important protein fractions because landraces are preferred by local consumers in the region. Protein content in common beans can be affected by different environments due to the variety of location interactions [24]. On the other hand, the protein content was slightly affected in cooked beans [25]. 
The fat contents of the modern varieties were between $0.33 \%$ and $1.33 \%$, while the fat contents of landraces were between $0.33 \%$ and $1.00 \%$ (Figure 2). Fat is an important organic acid with a very important place in human nutrition. The fat content was found to be $2.20 \%-5.03 \%$, linoleic acid content $33 \%$ and oleic acid content $9.5 \%$ on average [26]. LR11 (18.60\%) had the highest content of linoleic acid, one of the important fatty acids, while the modern variety MV06 had the lowest linoleic acid content among the accessions (Figure 2). The oleic acid and linoleic acid content of common bean cultivars was determined as $13.9 \%$ and $12.4 \%$, respectively [27]. Salunkhe et al. [28] reported that linoleic and linolenic fatty acids were dominant in the fat of beans. Oleic and linoleic acids in the common bean were determined as $7.8 \%-13.8 \%$ and $16.7 \%-25.8 \%$, respectively [29]. The oleic acid content in that study was lower than the current study findings, while the linoleic acid content was higher. The content of oleic acid in landraces was found to be higher (Figure 2) than the previous studies [26-29]. Omega fatty acids consisting of linolenic acid (Omega 3), linoleic acid (Omega 6) and oleic acid (Omega 9) help to protect against obesity, strengthen the immune system and prevent cholesterol. Omega fatty acids, in addition to being physiologically and biochemically essential for body functions, also play an important role in healthy tissue development [30]. Pari and Venkateswaran [31], reported that useful fatty acids such as oleic, linoleic and arachidonic acid levels were increased when diabetic rats were fed with beans.

Essential minerals such as Se, Fe and $\mathrm{Zn}$ are of great importance for human health [32]. Many researchers have reported that Se has important health benefits such as strengthening the immune system and lowering the risk of cancer [32,33]. There is also evidence that Se deficiency may lead to negative consequences with disease susceptibility [34,35]. In the current study, landrace LR05 had the highest Se content at $0.48 \mathrm{mg} / \mathrm{kg}$ and this was found to be an approximately 2-3-fold higher level than that of the other accessions (Figure 4).

$\mathrm{Zn}$ content in the landraces ranged from 17.81 to $37.90 \mathrm{mg} / \mathrm{kg}$, while the $\mathrm{Zn}$ content in the modern varieties ranged from 25.03 to $35.41 \mathrm{mg} / \mathrm{kg}$ (Figure 5). The highest $\mathrm{Zn}$ content was determined in landrace LR05 at $37.88 \mathrm{mg} / \mathrm{kg}$. The Zn content of landrace LR05 was higher than the findings of Koehler et al. [16] of $24 \pm 38 \mathrm{mg} / \mathrm{kg}$, and higher than the results $(17 \mathrm{mg} / \mathrm{kg})$ reported by Guzman-Maldonado et al. [13]. Although the $\mathrm{Zn}$ content of landraces was higher than results reported in most previous studies, it was not higher than that of modern cultivars (Figure 4) [16,17]. However, Barampama and Simard [11] reported $7.33 \mathrm{mg} Z \mathrm{Zn}$ per $100 \mathrm{~g}$, which was higher than that of the present study.

Anemia is generally caused by iron deficiency and there are greater numbers of anemic people in developing countries than in Europe and the USA [36,37]. The same researchers also found that $40 \%$ of Fe intake was provided by cereals and legumes. In the current study, Fe content was highest in MV03 (133.64 mg/kg), MV04 (116.31 mg/kg) and LR10 (115.05 mg/kg) (Figure 5). In the common bean, Gelin et al. [17] identified Fe content as $86.9 \mathrm{mg} / \mathrm{kg}$ among RILs, which was lower than the findings of the current study. The landrace LR10 and some modern varieties (MV03, MV04 and MV05) had a higher Fe content than the contents reported by Koehler et al. [16] and Guzman-Maldonado et al. [13]. These differences could be based on genotypes and environmental conditions. Furthermore, $\mathrm{Zn}$ content in the current study was significantly correlated with Se content $\left(\mathrm{r}=0.541^{* *}\right)$ and Fe content $\left(\mathrm{r}=0.628^{* *}\right)($ Table 1$)$.

\section{Materials and Methods}

\subsection{Bean Accessions}

The seeds of 15 common beans (Phaseolus vulgaris L.) comprising 10 accessions of landraces (LR02, LR03, LR04, LR05, LR06, LR07, LR08, LR09, LR10 and LR11) and 5 accessions of modern varieties (MV02, MV03, MV04, MV05, MV06) were evaluated for crude protein, fat, fatty acids, Se, Fe and $\mathrm{Zn}$ contents. The landraces were collected from farmers in smallholdings in the Western Taurus Mountains, while the modern varieties were obtained from international seed companies located in Antalya, Turkey. The Mountains are located at the western Mediterranean region of Turkey (at an 
altitude of 900-1200 $\mathrm{m}$ above sea level). The landraces in the target areas were preferred due to having considerable variations and are better preserved by the farmers in smallholdings. Bean accessions were grown in for two years under greenhouse conditions. The greenhouse experiment was conducted as a randomized complete block design with three replications. Plots were arranged as a single row of $2 \mathrm{~m}$ length with inter- and intra-row spacing of 50 and $20 \mathrm{~cm}$, respectively. After harvest, air-dried $150 \mathrm{~g}$ seeds of each bean accession were ground using hand milling for the following analyses. The analyses were performed in two replicates, and carried out by Food Safety and Agricultural Research Center, Akdeniz University.

\subsection{Crude Protein}

Crude protein was determined according to the Kjeldahl method, multiplied by the $6.25(\mathrm{~N} \times 6.25)$ conversion factor, and the results were then calculated as a percentage (\%) according to AOAC [38].

\subsection{Fat and Fatty Acids Analyses}

The seeds of each common bean accession were subjected to oil extraction using a Dionex Accelerated Solvent Extractor (Dionex ASE 300 ${ }^{\mathrm{TM}}$ : Sunyvale, CA, USA). The fat content of the seed samples was determined according to the method of Uzun et al. [39]. The composition of fatty acids was determined with thermo trace GC (gas chromatography) ultra (San Jose, CA, USA) and standards were evaluated according to the method of Uzun et al. [39]. The fat and fatty acids of the accessions were reported as percentages $(\%)$.

\subsection{Mineral Content}

$\mathrm{Se}, \mathrm{Fe}$ and $\mathrm{Zn}$ contents were analyzed in the ash solution, using an ICP-MS (Inductively coupled plasma-mass spectrophotometer) (Perkin Elmer ELAN DCR-e equipped with a Scott Spray Chamber 103: Norwalk, CT, USA) as previously described [40], and determined as $\mathrm{mg} / \mathrm{kg}$.

\subsection{Soil Analyses}

According to soil analyses in the greenhouse, organic matter $(1.2 \%)$ and nitrogen $(0.09 \%)$ were found to be at a low level. Soil texture, $\mathrm{pH}$ and $\mathrm{CaCO}_{3}$ were loam, 8.0 and $17.6 \%$, respectively. Available $\mathrm{P}, \mathrm{Fe}, \mathrm{Zn}, \mathrm{Mn}$ and $\mathrm{Cu}$ were detected as 24.74, 5.11, 1, 27.74 and $1.26 \mathrm{mg} / \mathrm{kg}$, respectively. Exchangeable $\mathrm{K}, \mathrm{Ca}$ and $\mathrm{Mg}$ were found as $17.6 \mathrm{mg}, 652 \mathrm{mg}$ and $14.6 \mathrm{mg} / 100 \mathrm{~g}$, respectively.

\subsection{Statistical Analyses}

Data related to the nutritional components, $\mathrm{Se}, \mathrm{Fe}, \mathrm{Zn}$, were subjected to analysis of variance (ANOVA) with SPSS 22.0 software (SPSS: Chicago, IL, USA). The results were reported as statistics with a value of $P<0.05$ accepted as statistically significant. Duncan's multiple range test (DMRT) was applied to compare to bean accessions. The different upper- or lower-case letters on the bars indicate significant difference, while the same upper- or lower-case letters are not significantly different $(P<0.05)$. Correlation coefficients $(r)$ of all the nutritional contents were determined using XLTAT 2018 version 2.50918 (Addinsoft: Paris, France).

\section{Conclusions}

The results of the present study showed that landrace LR05 had better crude protein, Se and Zn content than modern varieties. Landrace LR11 had the highest linoleic acid. These results indicate that the landraces of the common bean are not only treasures that need to be transferred to the future but also genetic resources that can be used in bean breeding programs. The results suggest that landraces are significant sources of important nutritional components for food security and a healthy food supply. 
Author Contributions: T.C. wrote a thesis in Turkish, H.S. translated the thesis from Turkish into English and H.C. collected landraces. Plants were grown by T.C., H.S., D.S., A.A. and T.E. Analyses were performed by T.C. and H.S. As the supervisor, T.C. managed the grants that funded this work. All authors read and then approved the final manuscript.

Funding: This research was funded by Akdeniz University with grant number FYL-2017-3139.

Acknowledgments: Phenological, morphological and agronomical traits were not given in the current study, a part of the Master Science thesis of the first author (T.C.). We fully appreciate editors and all anonymous reviewers have done.

Conflicts of Interest: We have declared that no conflict of interests.

\section{References}

1. Freytag, G.F.; Debouck, D.G. Review of taxonomy, distribution, and ecology of the genus Phaseolus (Leguminosae Papilionoideae) in North America, Mexico, and Central America. Sida Bot. Misc. 2002, 23, 1-300.

2. Delgado-Salinas, A.; Bibler, R.; Lavin, M. Phylogeny of the genus Phaseolus (Laguminosae): A recent diversification in an ancient landscape. Syst. Bot. 2006, 31, 779-791. [CrossRef]

3. Smykal, P.; Coyne, C.J.; Ambrose, M.J.; Maxted, N.; Schaefer, H.; Blair, M.W.; Berger, J.; Greene, S.L.; Nelson, M.N.; Besharat, N.; et al. Legume crops phylogeny and genetic diversity for science and breeding. Crit. Rev. Plant Sci. 2015, 34, 43-104. [CrossRef]

4. Singh, S.P. Common Bean Improvement in the Twenty-First Century; Singh, S.P., Ed.; Kluwer Academic Publishers: Dordrecht, The Netherlands, 1999.

5. FAOSTAT. FAOSTAT Crop Statistics. Available online: http://faostat.fao.org/site/567/DesktopDefault.aspx (accessed on 5 March 2018).

6. Beshir, H.M.; Walley, F.L.; Bueckert, R.; Tar'an, B. Response of snap bean cultivars to Rhizobium inoculation under dryland agriculture in Ethiopia. Agronomy 2015, 5, 291-308. [CrossRef]

7. Reyes-Moreno, C.; Paredes-Lopez, O. Hard-to-cook phenomenon in common beans-a review. CRC Crit. Rev. Food Sci. Nutr. 1993, 33, 227-286. [CrossRef] [PubMed]

8. Lucier, G.; Lin, B.H.; Allshouse, J.; Kantor, L.S. Factors affecting dry bean consumption in the United States. Small 2000, 19, 2-5.

9. Augustin, J.; Beck, C.B.; Kalbfleish, G.; Kagel, L.C.; Matthews, R.H. Variation in the vitamin and mineral content of raw and cooked commercial Phaseolus vulgaris classes. J. Food Sci. 1981, 46, 1701-1706. [CrossRef]

10. Sangronis, E.; Machado, C.J. Influence of germination on the nutritional quality of Phaseolus vulgaris and Cajanus cajan. LWT Food Sci. Technol. 2007, 40, 116-120. [CrossRef]

11. Barampama, Z.; Simard, R.E. Nutrient composition, protein quality and antinutritional factors of some varieties of dry beans (Phaseolus vulgaris) grown in Burundi. Food Chem. 1993, 47, 159-167. [CrossRef]

12. Beebe, S.; Gonzalez, A.V.; Rengifo, J. Research on trace minerals in the common bean. Food Nutr. Bull. 2000, 21, 387-391. [CrossRef]

13. Guzman-Maldonado, S.H.; Acosta-Gallegos, J.; Paredes-Lopez, O. Protein and mineral content of a novel collection of wild and weedy common bean (Phaseolus vulgaris L). J. Sc. Food Agric. 2000, 80, 1874-1881. [CrossRef]

14. Brigide, P.; Canniatt-Brazaca, S.G.; Silva, M.O. Nutritional characteristics of biofortified common beans. Food Sci. Technol. 2014, 34, 493-500. [CrossRef]

15. Grela, E.R.; Samolinska, W.; Kiczorowska, B.; Klebaniuk, R.; Kiczorowski, P. Content of minerals and fatty acids and their correlation with phytochemical compounds and antioxidant activity of leguminous seeds. Biol. Trace Elem. Res. 2017, 180, 338-348. [CrossRef] [PubMed]

16. Koehler, H.H.; Chang, C.H.; Scheier, G.; Burke, D.W. Nutrient composition, protein quality, and sensory properties of thirty-six cultivars of dry beans (Phaseolus vulgaris L.). J. Food Sci. 1987, 52, 1335-1340. [CrossRef]

17. Gelin, J.R.; Forster, S.; Grafton, K.F.; McClean, P.E.; Rojas-Cifuentes, G.A. Analysis of seed zinc and other minerals in a recombinant inbred population of navy bean (Phaseolus vulgaris L.). Crop Sci. 2007, 47, 1361-1366. [CrossRef] 
18. Mahajan, R.; Zargar, S.M.; Salgotra, R.K.; Singh, R.; Wani, A.A.; Nazir, M.; Sofi, P.A. Linkage disequilibrium based association mapping of micronutrients in common bean (Phaseolus vulgaris L.): A collection of Jammu \& Kashmir, India. 3 Biotech 2017, 7, 295. [PubMed]

19. Ray, H.; Bett, K.; Tar'an, B.; Vandenberg, A.; Thavarajah, D.; Warkentin, T. Mineral micronutrient content of cultivars of field pea, chickpea, common bean, and lentil grown in Saskatchewan, Canada. Crop Sci. 2014, 54, 1698-1708. [CrossRef]

20. Smykal, P.; Nelson, M.N.; Berger, J.D.; von Wettberg, E.J. The Impact of Genetic Changes during Crop Domestication on Healthy Food Development. Agronomy 2018, 8, 26. [CrossRef]

21. Hammer, K.; Knupffer, H.; Xhuveli, L.; Perrino, P. Estimating genetic erosion in landraces two case studies. Genet. Resour. Crop Evol. 1996, 43, 329-336. [CrossRef]

22. Miles, C.; Atterberry, K.A.; Brouwer, B. Performance of northwest Washington heirloom dry bean varieties in organic production. Agronomy 2015, 4, 491-505. [CrossRef]

23. Ma, Y.; Bliss, F.A. Seed proteins of common bean. Crop Sci. 1978, 18, 431-437. [CrossRef]

24. Florez, A.; Pujola, M.; Valero, J.; Centelles, E.; Almirall, A.; Casanas, F. Genetic and environmental effects on chemical composition related to sensory traits in common beans (Phaseolus vulgaris L.). Food Chem. 2009, 113, 950-956. [CrossRef]

25. Pujola, M.; Farreras, A.; Casanas, F. Protein and starch content of raw, soaked and cooked beans (Phaseolus vulgaris L.). Food Chem. 2007, 102, 1034-1041. [CrossRef]

26. Srivastava, R.P.; Kumar, L.; Srivastava, G.K. Nutritional composition and fatty acid profile of rajmash beans (Phaseolus vulgaris). Indian J. Agric. Biochem. 2004, 17, 63-65.

27. Grela, E.R.; Gunter, K.D. Fatty acid composition and tocopherol content of some legume seeds. Anim. Feed Sci. Technol. 1995, 52, 325-331. [CrossRef]

28. Salunkhe, D.K.; Sathe, S.K.; Reddy, N.R. Legume lipids. In Chemistry and Biochemistry of Legumes; Arora, S.K., Arnold, E., Eds.; Hodder Arnold H\&S: London, UK, 1983; pp. 51-97.

29. Yoshida, H.; Tomiyama, Y.; Kita, S.; Mizushina, Y. Lipid classes, fatty acid composition and triacylglycerol molecular species of kidney beans (Phaseolus vulgaris L.). Eur. J. Lipid Sci. Technol. 2005, 107, 307-315. [CrossRef]

30. Gomez-Candela, C.; Bermejo-Lopez, L.M.; Loria-Kohen, V. Importance of a balanced omega 6/omega 3 ratio for the maintenance of health. Nutritional recommendations. Nutr. Hosp. 2011, 26, 323-329. [PubMed]

31. Pari, L.; Venkateswaran, S. Protective role of Phaseolus vulgaris on changes in the fatty acid composition in experimental diabetes. J. Med. Food 2004, 7, 204-209. [CrossRef] [PubMed]

32. Rayman, M.P. The importance of selenium to human health. Lancet 2000, 356, 233-241. [CrossRef]

33. Sunde, R.A. Selenium. In Handbook of Nutritionally Essential Mineral Elements; O'Dell, B.L., Sunde, R.A., Eds.; Marcel Dekker Inc.: New York, NY, USA, 1997; pp. 493-556.

34. Spallholz, J.E.; Boylan, L.M.; Larsen, H.S. Advances in understanding selenium's role in the immune system. Ann. N.Y. Acad. Sci. 1990, 587, 123-139. [CrossRef] [PubMed]

35. Neve, J. Selenium as a risk factor for cardiovascular diseases. J. Cardiovasc. Risk 1996, 3, 42-47. [CrossRef] [PubMed]

36. Barclay, D.V.; Heredia, L.; Gil-Ramos, J.; Montalvo, M.M.; Lozano, R.; Mena, M.; Dirren, H. Nutritional status of institutionalized elderly in Ecuador. Arch. Latinoam. Nutr. 1996, 46, 122-127. [PubMed]

37. Rosado, J.L.; Lopez, P.; Morales, M.; Munaoz, E.; Allen, L.H. Bioavailability of energy, nitrogen, fat, zinc, iron and calcium from rural and urban Mexican diets. Br. J. Nutr. 1992, 68, 45-58. [CrossRef] [PubMed]

38. AOAC. Official Methods of Analysis, 15th ed.; Association of Official Analytical Chemists: Arlington, VA, USA, 1990.

39. Uzun, B.; Arslan, C.; Karhan, M.; Toker, C. Fat and fatty acids of white lupin (Lupinusalbus L.) in comparison to sesame (Sesamum indicum L.). Food Chem. 2007, 102, 45-49. [CrossRef]

40. Topuz, O.K.; Yerlikaya, P.; Yatmaz, H.A.; Kaya, A.; Alp, A.C.; Kilic, M. Comparison of essential trace element profiles of rainbow trout fish (Oncorhynchus mykiss) meat and egg. Sci. Pap. Ser. D Anim. Sci. 2017, 60, 316-319. 